\title{
Hospital Ash Waste-Ordinary Portland Cement Concrete
}

\author{
Augustine U. Elinwa \\ Civil Engineering Department, Abubakar Tafawa Balewa University, Bauchi, Nigeria
}

Email address:

auelinwa@gmail.com

\section{To cite this article:}

Augustine U. Elinwa. Hospital Ash Waste-Ordinary Portland Cement Concrete. Science Research. Vol. 4, No. 3, 2016 , pp. $72-78$. doi: 10.11648/j.sr.20160403.11

Received: March 2, 2016; Accepted: April 8, 2016; Published: June 7, 2016

\begin{abstract}
This work is part of the on-going research work in the Civil Engineering Department of Abubakar Tafawa Balewa University, Bauchi Nigeria. The work is on characterizing and utilization of hospital waste ash (HWA) in the production of concrete. This work is important in the light of the recent happenings in Nigeria, where cases of Ebola and Lassa fever diseases have been mentioned and most recently, the fear of the Zika disease. The need for adequate study on the data on management, handling and disposal of hospital waste, is of paramount importance to prevent relapse A study on the incineration ash was undertaken in order to assess the material's adequacy for concrete production. The results showed that the ash contains relatively high percentage of $\mathrm{CaO}(47 \%)$, which has cementing value and thus, can be used for cement manufacture. The hydration characteristics showed it is pozzolanic in nature and the setting times values showed that HWA can be used as a retarder, especially for hot weather concreting. The ash was used as partial replacements for cement in proportions of 0 to $40 \%$ by weight of cement to make concrete cubes that were cured for periods of 3 days to 90 days. The results showed that water absorption increased with increase in the replacement levels, while the compressive strength decreased accordingly. The work was taken further by developing statistical relationships between the slump, water absorption and compressive strengths.
\end{abstract}

Keywords: Hospital Waste Ash, Pozzolan, Compressive Strengths, Water Absorption, Statistical Analysis

\section{Introduction}

Hospital waste is a special category of waste. It is highly hazardous due to its infectious and/or toxic characteristics [1, 2]. The management, handling and disposal of these wastes have become a growing environmental concern mostly in the developing countries, not minding the differences that occur in the current medical waste management practices from hospital to hospital $[1,3]$. The consequences of which may increase the airborne pathogenic bacteria, which could adversely affect the hospital environment and community at large. The recent outbreaks of Ebola, Lassa fever and Zika infections are great concerns in Nigeria. Bassey et al [4] in their study on characterization and evaluation of waste disposal techniques employed in the management of solid medical wastes generated in the five selected hospitals in the Federal Capital Territory (FCT), Abuja, Nigeria, confirmed that medical waste has received very little attention in waste management process in Nigeria. Also, other researchers on medical wastes in Nigeria have also expressed the same concern on the level of awareness in the management of these wastes [5].

Improper waste management can lead to environmental pollution [6] and create health hazard to institutions believed to be bringing relief to the sick. The proper collection and disposal of hospital wastes will not only reduce the volume infectious wastes and cost of treatment, but will also promote healthy environment and good living.

The hospital wastes (HW) generated in Abubakar Tafawa Balewa University Teaching Hospital, Bauchi, Nigeria, is the focus in this research. This is because it is an environment, where hosts of activities are carried out. The hospital wastes generated fall into three categories, namely: medical waste, infectious waste and domestic waste. The medical waste is taken to be materials accumulated due to patient diagnosis, treatment or immunization while the infectious waste is that portion of medical waste that is in contact with a patient that has infectious disease [7]. The waste in Abubakar Tafawa Balewa Teaching Hospital is considered to be an infectious waste because the medical waste and other wastes are not 
collected separately. The hospital, generates a total waste of $545 \mathrm{~kg} /$ month of which $15 \%$ of this is classified as infectious [6] giving a value of approximately $82 \mathrm{~kg} /$ month. Segregation of the wastes at the points of collections is not practiced as specified by World Health Standards [8]. The prevailing practice is general collection of the wastes which are dumped as refuse site and later burned openly or dumped in the landfill.

Incineration has been adopted as the most efficient method of reducing the waste volume [9]. This method has its attendant shortcoming. They are source of contaminants to the soil as well as surface and underground water due to the heavy metal toxicity and presence of dioxins and furans $[10$, 11]. Recent researches have shown that the ashes of these wastes can be properly utilized in cement and concrete works $[12,13]$, road and asphalt aggregate $[14,15]$ and hydraulic barriers [16]. Mineral additions to Portland cement materials have been found to offer an ecological solution to safe disposal of waste materials [12]. The mechanical properties of the medical waste incineration bottom ash using different amounts of ordinary Portland cement (OPC) as binder have been investigated by Anastasiadou et al., [17]. The solidified matrix showed that cement was able to immobilize the heavy metals found in fly and bottom ash [2]. Different mixes were prepared by Filipponi et al., [18] by blending hospital waste incinerator bottom ash with ordinary Portland cement in different proportions and at different water dosages. The solidified products were then tested for the unconfined compressive strength (UCS) at different curing times. Results at curing times longer than 28 days and for waste dosage higher than $50 \%$ suggested that bottom ash exhibited weak pozzolanic property [2].

Majority of the researches in Nigeria are on the management, handling and disposal, of these wastes. Little or no attention has been given to using the incineration ashes for cement and concrete production. The present study therefore, is to use the hospital waste ash (HWA) as replacement material for cement to produce concrete specimens. The work is aimed at evaluating its effects on the final properties of the concrete specimens. It is also the aim of this work to use statistical inferences to estimate and test the marginal effects of each factor (main effects) and joint effect (interaction), if any, in developing a statistical relationship.

\section{Materials}

The ash used for this research work was taken from the incinerator point (open burning) of Abubakar Tafawa Balewa University Teaching Hospital, Bauchi, Nigeria. The method of incineration is open burning. The chemical properties of the ash collected from the incinerator are shown in Table 1, and has a moisture content of $6.5 \%$ and a density of 2.4 $\mathrm{kg} / \mathrm{m}^{3}$. This was carried out at the National Metallurgical Development Centre, Jos, Plateau State, Nigeria. The HWA was grinded and sieved using a sieve size of $150 \mu \mathrm{m}$.
Table 1. Chemical Composition of HWA.

\begin{tabular}{ll}
\hline Compound & Present \\
\hline $\mathrm{SiO}_{2}$ & 20.60 \\
$\mathrm{P}_{2} \mathrm{O}_{5}$ & 0.95 \\
$\mathrm{SO}_{3}$ & 1.50 \\
$\mathrm{Cl}$ & 2.38 \\
$\mathrm{~K}_{2} \mathrm{O}$ & 9.78 \\
$\mathrm{TiO}_{2}$ & 1.20 \\
$\mathrm{CaO}$ & 47.43 \\
$\mathrm{~V}_{2} \mathrm{O}_{5}$ & 0.04 \\
$\mathrm{Cr}_{2} \mathrm{O}_{3}$ & 0.04 \\
$\mathrm{MnO}$ & 0.22 \\
$\mathrm{Fe}_{2} \mathrm{O}_{3}$ & 8.06 \\
$\mathrm{NiO}$ & 0.01 \\
$\mathrm{CuO}$ & 0.08 \\
$\mathrm{ZnO}$ & 0.19 \\
$\mathrm{Br}_{\mathrm{SrO}}$ & 0.02 \\
$\mathrm{ZrO}$ & 0.41 \\
$\mathrm{BaO}$ & 0.33 \\
$\mathrm{PbO}$ & 0.54 \\
$\mathrm{Ag}_{2} \mathrm{O}$ & 0.03 \\
\hline
\end{tabular}

The cement used is Ashaka Portland cement and conforms to EN 197-1 [19]. The physical and chemical properties are given in Table 2. The fine aggregate is river sand with a specific gravity of 2.64 , bulk density $1457 \mathrm{~kg} / \mathrm{m}^{3}$, and moisture content of $2.56 \%$. The sieve analysis is shown in Table 3 and falls under zone 2 of the classification chart. The coarse aggregate is $20 \mathrm{~mm}$ with a bulk density of 1552 $\mathrm{kg} / \mathrm{m}^{3}$, aggregate impact value (AIV) $13.5 \%$ and aggregate crushing value (ACV) of $6.6 \%$. It also falls into zone 2 of the classification chart.

Table 2. Physical and Chemical Properties of Ashaka Portland Cement.

\begin{tabular}{ll}
\hline Specific gravity & 3.15 \\
Loose bulk density $\left(\mathrm{kg} / \mathrm{m}^{3}\right)$ & 3150 \\
Loss on ignition $(\%)$ & 1.0 \\
Specific surface $\left(\mathrm{m}^{2} / \mathrm{g}\right)$ & 2.30 \\
Soundness $(\mathrm{mm})$ & 8.0 \\
Chemical Properties & \\
$\mathrm{Chemical} \mathrm{Constituents}$ & Percentage by Weight $(\%)$ \\
$\mathrm{CaO}$ & 63.7 \\
$\mathrm{SiO}_{2}$ & 19.9 \\
$\mathrm{Al}_{2} \mathrm{O}_{3}$ & 5.6 \\
$\mathrm{Fe}_{2} \mathrm{O}_{3}$ & 2.9 \\
$\mathrm{SO}_{3}$ & 2.3 \\
$\mathrm{MgO}$ & 1.5 \\
$\mathrm{Na}_{2} \mathrm{O}$ & 0.2 \\
$\mathrm{~K}_{2} \mathrm{O}$ & 0.7 \\
\hline
\end{tabular}

Table 3. Sieve Analysis of the Fine Aggregate.

\begin{tabular}{ll}
\hline BS Sieve Size & Percentage Passing (\%) \\
\hline $5.00 \mathrm{~mm}$ & 100 \\
$2.00 \mathrm{~mm}$ & 96.4 \\
$1.18 \mathrm{~mm}$ & 74.9 \\
$600 \mu \mathrm{m}$ & 35.9 \\
$300 \mu \mathrm{m}$ & 16.3 \\
$150 \mu \mathrm{m}$ & 5.5 \\
$63 \mu \mathrm{m}$ & 1.8 \\
\hline
\end{tabular}




\section{Experimental Programme}

Experiments were carried out in the fresh conditions for the pozzolanic activity (PAI), soundness, consistency and initial and final setting times of the HWA-OPC pastes. Tables 4 and 5 are results of the soundness, consistency, setting times and pozzolanic activity index (PAI) of the HWA-OPC pastes, respectively. The tests were conducted in accordance with American Standard Codes [20, 21].

Table 4. Soundness, Consistency and Setting Times.

\begin{tabular}{lllll}
\hline \multirow{2}{*}{ Mix No } & \multirow{2}{*}{ Soundness $(\mathbf{m m})$} & Consistency (\%) & \multicolumn{2}{c}{ Setting Times (Min) } \\
\cline { 4 - 5 } & & & Initial & Final \\
\hline M-00 & 12.2 & 29 & 45 & 496 \\
M-10 & 11.0 & 34 & 185 & 876 \\
M-20 & 9.6 & 36 & 300 & 985 \\
M-30 & 11.3 & 39 & 490 & 1075 \\
M-40 & 13.3 & 41 & 690 & 1100 \\
\hline
\end{tabular}

Table 5. Pozzolanic Activity Index.

\begin{tabular}{lll}
\hline Mix No & Mean Strength $\left(\mathbf{N} / \mathbf{m m}^{\mathbf{2}}\right)$ & PAI (\%) \\
\hline M-00 & 25.0 & 85 \\
M-10 & 21.5 & \\
\hline
\end{tabular}

Experiments in the hardened condition were carried out using a mix ratio of $1: 1.6: 2.5$ with a water-cement ratio (w/c) of 0.5 . Five mixes: M-00, M-10, M-20, M-30 and M40 , were used for the slump, density, water absorption and compressive strength of the HWA-OPC concrete. The mix designations show the various replacement levels of cement by HWA by weight percent. The mix labeled M-00 is the control. The slump was taken immediately after the mixing using three measurements and averaging. These were done in accordance with C143/C143M-12 [22]. The results are shown in Table 6 .

Table 6. Slump of HWA-OPC Concrete.

\begin{tabular}{ll}
\hline Mix No & Slump $(\mathbf{m m})$ \\
\hline M-00 & 25 \\
M-10 & 21 \\
M-20 & 20 \\
M-30 & 19 \\
M-40 & 15 \\
\hline
\end{tabular}

\section{i) Density and Water Absorption Tests}

Seventy five (75) specimens were cast and cured for 3, 7, 28, 60 and 90 days using cubic moulds of $150 \mathrm{~mm}$ for the tests on density, water absorption and compressive cube strengths. The average of three test specimens was taken at the end of each curing regime. The density and water absorption tests were done in accordance with ASTM C64213 [23], and the results shown in Tables 7 and 8, respectively. For the compressive cube strength tests, they were conducted in accordance with ASTM C192/C192M [24] using an ELE compression machine to test the cubes to failure. Table 9 shows the values of the cube compressive strength results.
Table 7. Density of HWA-OPC Concrete.

\begin{tabular}{llllll}
\hline \multirow{2}{*}{ Mix No } & \multicolumn{5}{l}{ Density $\left(\mathbf{k g} / \mathbf{m}^{\mathbf{3}}\right)$} \\
\cline { 2 - 6 } & $\mathbf{3 ~ d}$ & $\mathbf{7 ~ d ~}$ & $\mathbf{2 8 ~ d}$ & $\mathbf{6 0 ~ d}$ & $\mathbf{9 0 ~ d}$ \\
\hline M-00 & 2455 & 2489 & 2490 & 2595 & 2624 \\
M-10 & 2444 & 2454 & 2473 & 2493 & 2493 \\
M-20 & 2454 & 2459 & 2459 & 2483 & 2493 \\
M-30 & 2434 & 2545 & 2439 & 2459 & 2454 \\
M-40 & 2437 & 2424 & 2444 & 2459 & 2448 \\
\hline
\end{tabular}

Table 8. Water Absorption of HWA-OPC Concrete.

\begin{tabular}{llllll}
\hline \multirow{2}{*}{ Mix No } & \multicolumn{5}{l}{ Water Absorption (\%) } \\
\cline { 2 - 6 } & $\mathbf{3 ~ d}$ & $\mathbf{7 d}$ & $\mathbf{2 8 ~ d}$ & $\mathbf{6 0} \mathbf{d}$ & $\mathbf{9 0 ~ d}$ \\
\hline M-00 & 2.0 & 2.0 & 6.6 & 11.4 & 12.0 \\
M-10 & 2.0 & 2.1 & 6.6 & 10.8 & 12.0 \\
M-20 & 2.0 & 4.0 & 7.3 & 10.8 & 11.9 \\
M-30 & 3.0 & 4.6 & 6.7 & 11.3 & 11.7 \\
M-40 & 2.7 & 4.3 & 8.3 & 10.8 & 12.2 \\
\hline
\end{tabular}

Table 9. Compressive Strengths of HWA-OPC Concrete.

\begin{tabular}{ll|llll}
\hline \multirow{2}{*}{ Mix No } & \multicolumn{6}{l}{ Compressive Strength (MPa) } \\
\cline { 2 - 6 } & $\mathbf{3 ~ d}$ & $\mathbf{7 ~ d ~}$ & $\mathbf{2 8 ~ d}$ & $\mathbf{6 0 ~ d}$ & $\mathbf{9 0 ~ d}$ \\
\hline M-00 & 17.2 & 20.9 & 25.0 & 30.1 & 31.3 \\
M-10 & 15.5 & 18.5 & 21.5 & 23.2 & 28.2 \\
M-20 & 13.0 & 16.7 & 20.0 & 21.8 & 24.1 \\
M-30 & 10.6 & 14.4 & 18.3 & 20.0 & 22.4 \\
M-40 & 9.8 & 12.9 & 16.5 & 19.5 & 20.9 \\
\hline
\end{tabular}

\section{Discussions}

Table 1 shows the chemical characteristics of the HWA. The $\mathrm{CaO}$ in the HWA is approximately $47 \%$. This is approximately $70 \%$ the value content in cement. $\mathrm{CaO}$ is the cementing factor in cement and thus the HWA can also be used for cement production. The $\mathrm{SiO}_{2}$ and $\mathrm{Fe}_{2} \mathrm{O}_{3}$ contents are approximately $21 \%$ and $8 \%$ respectively, but $\mathrm{Al}_{2} \mathrm{O}_{3}$ is not detected. It is not clear meanwhile why $\mathrm{Al}_{2} \mathrm{O}_{3}$ is not detected. Genazzini et al [12], analysed ash from the incinerator of $\mathrm{HW}$ in a local facility, in the La Plata area, Argentina. The chemical characteristics of the ash has the following composition: $\mathrm{CaO}$ (33.18\%), $\mathrm{Al}_{2} \mathrm{O}_{3}$ (14.34\%), $\mathrm{Fe}_{2} \mathrm{O}_{3}(4.64 \%)$ and $\mathrm{SiO}_{2}(0.39 \%)$. The silica content is low (less than $1 \%$ ), but with an aluminum oxide of $14.34 \%$. Results from Shazim et al [13], working with HWA obtained from Pakistan Institute of Medical Sciences, Rawalpindi, Pakistan, had $\mathrm{SiO}_{2}$ (19.6\%), $\mathrm{Al}_{2} \mathrm{O}_{3}$ (10.4\%), $\mathrm{Fe}_{2} \mathrm{O}_{3}(6.3 \%)$ and $\mathrm{CaO}$ (36.6\%). This is more in agreement with the findings of this present research. The area of difference is with $\mathrm{Al}_{2} \mathrm{O}_{3}$. The level of $\mathrm{CaO}$ content in the ash shows that the HWA has cementing factor. Incinerator ash characteristics from different sources have been confirmed to have some differences [2]. The density of fly ash was found in the range $0.37-0.82 \mathrm{~kg} / \mathrm{m}^{3}$ and the density of bottom ash was found in the range 0.73 $1.04 \mathrm{~kg} / \mathrm{m}^{3}$ [25]. A value of $2.5 \mathrm{~kg} / \mathrm{m}^{3}$ density has been reported. Preliminary tests carried out on the HWA/OPC mixture to determine the pozzolanic activity as per British Standard Specifications gave a pozzolanic activity index of $85 \%$.

Figure 1 shows the effect of replacing part of the cement with HWA on the soundness, water affinity and slump. It is 
observed that at $20 \%$ replacement, the value of the soundness $(9.6 \mathrm{~mm})$ is within the code specification of $10 \mathrm{~mm}$. However, within experimental errors, the values of $11.0 \mathrm{~mm}$ and $11.3 \mathrm{~mm}$, at replacement levels of $10 \%$ and $30 \%$ respectively, can be accepted as okay. The water requirement of HWA increased as the percentage replacement increased. The percentage increase ranged from $17 \%$ to $41 \%$ of the control. The reason for this may be due to the morphology of the ash. The same behaviour has been observed for bottom ash and thus, was attributed to higher porosity of bottom ash which absorbed water and resulted in higher water requirement [26]. The slump of HWA-concrete decreased as the proportions of HWA increased and thus, the workability. This may be attributed to the void filling action of the waste HWA as it is finer than the fine aggregate, which gives a high cohesion to the mix. However in another research where incineration ash was used in replacing sand, the slump decreased but increased when used in replacing cement [27]. This however, needs further investigations. The density of HWA-concrete is a normal weight concrete as shown in Table 7, and decreases as the HWA replacement level increased. Similar observation has been made by Genazzini et. el [12].

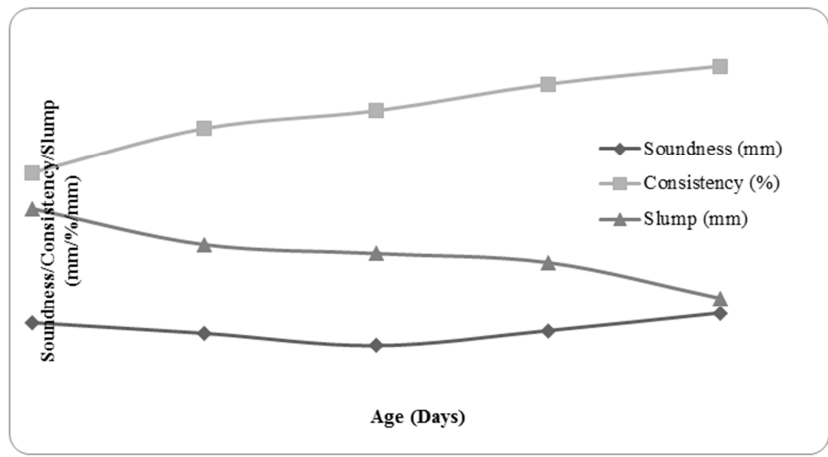

Figure 1. Soundness/Consistency/Slump.

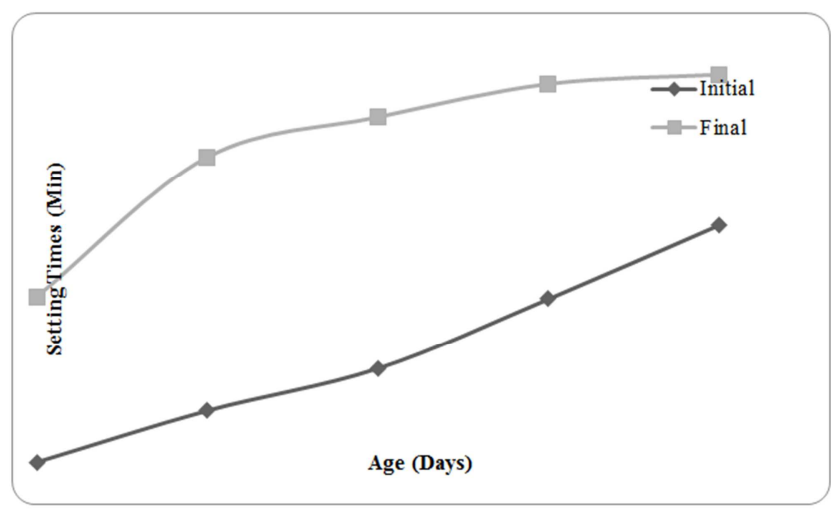

Figure 2. Setting Times (Min.).

The setting time of HWA/OPC is important for practical applications of the material. This was determined using the Vicat method [28] and shown in Fig. 2. This shows that HWA/OPC paste conforms to specifications for setting times for similar materials and that HWA could be classified as a retarder. This will be suitable for hot weather concreting to keep the concrete workable for a long time. Lavat and Trezza in [12] was reported to confirm the detrimental effects of ashes on setting time by observing the influence of $\mathrm{Pb}$ in the inhibition of early cement hydration. Stephan et al [29], analysed the influence of $\mathrm{Cr}, \mathrm{Ni}$, and $\mathrm{Zn}$ on the structure and reactivity of clinker phases. It was observed that these heavy metals have only minor effects on setting and hydration of cement mortars even in concentrations $10-20$ times higher than those usually present in Portland cement [12]. At very high concentrations of $\mathrm{Cr}$, the rate of setting and hydration reactions increased but delayed in the presence of high content of $\mathrm{Zn}$ while no significant effects were observed when high contents of $\mathrm{Ni}$ were incorporated [12].

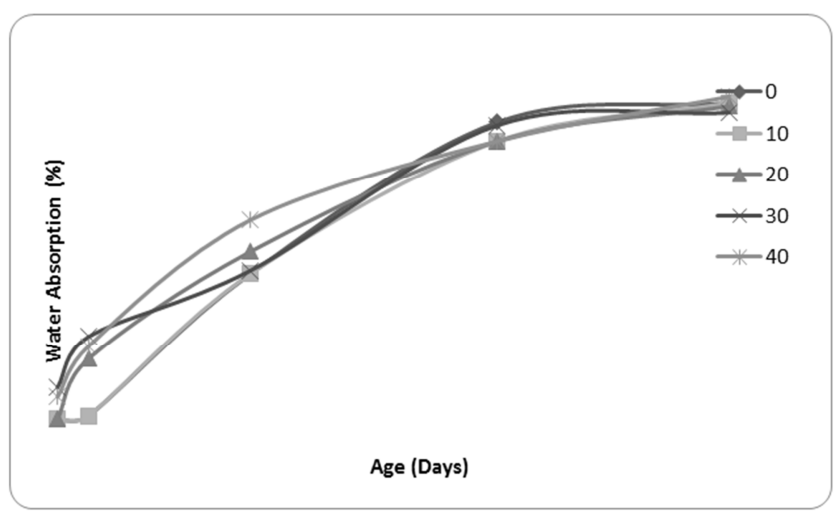

Figure 3. Water Absorption for HWA-Concrete (\%).

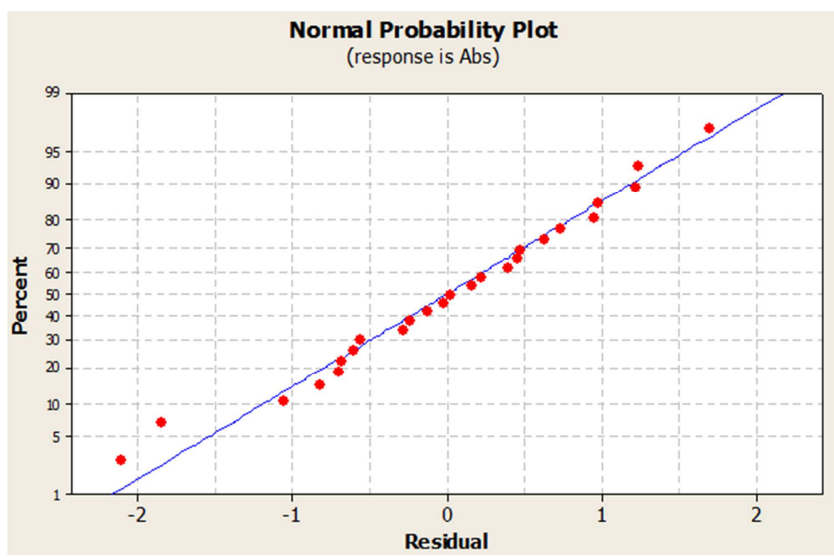

Figure 4. Normality Plot (Water Absorption).

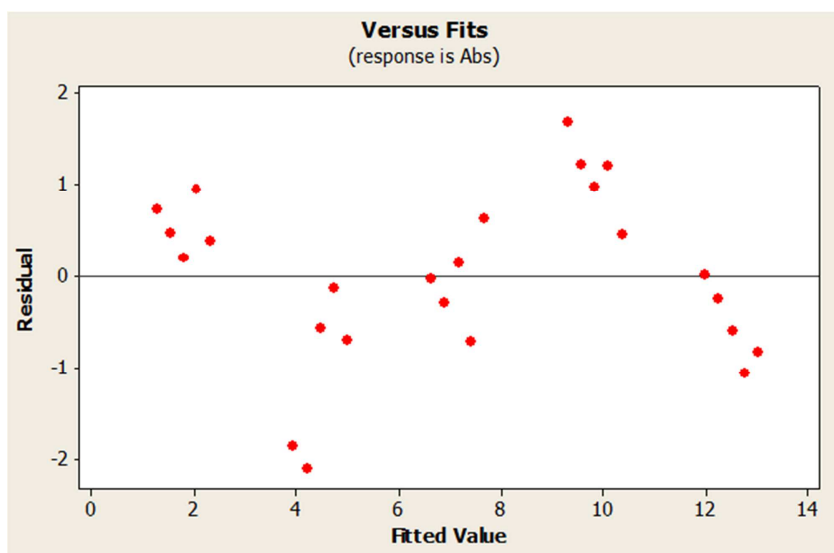

Figure 5. Residual Plot (Water Absorption). 
Figure 3 and Table 7 are the water absorption plot and density of HWA-concrete. They show that as HWA increases there is increase in water absorption and decrease in density. Water absorption and porosity are important indicators of the durability of hardened concrete. Increased water absorption and porosity and decrease in density, have been reported by Genazzini et al [12] These are some of the reasons for the decrease in compressive strength. They recommended that the use of an admixture will improve the compressive strength. A linear model of the form: $w a=a_{l}$ $+b_{1} x_{1}+c_{1} x_{2}$, can be used to represent the statistical behavior of the water absorption of HWA-concrete. The constants $a_{l}, b_{1}$ and $c_{1}$ are given as $-1.67 ; 0.260$ and 2.68, respectively. The variables, $x_{1}$ and $x_{2}$, are HWA replacement levels (\%) and age of curing, respectively. The standard deviation and correlation factor $\left(r^{2}\right)$ are 0.9723 and $94.6 \%$, respectively. The correlation shows that the interaction of the HWA and age is approximately $95 \%$. The relevance of the model chosen (ANOVA), has a $p$-value equal to 0.000 , which is very significant. The normality and scatter plots on the data collected are shown in Figures 4 and 5, respectively. They confirm that the linear model chosen as relevant.

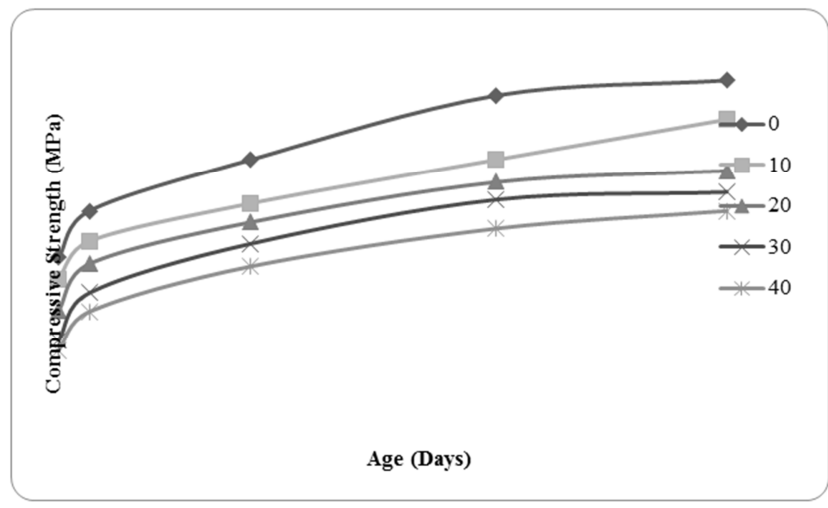

Figure 6. Compressive Strengths of HWA-Concrete (MPa).

Table 9 is the compressive strength development of HWAconcrete. It shows that as HWA replacement level increases, the compressive strength decreases. It is also recorded [12], that at very high concentrations of $\mathrm{Cr}$, the rate of setting and hydration reaction increases and strength decreases. This may be adduced as probably one of the reasons the strength of the HWA-concrete decreased. However, the best performance was at $10 \%$ HWA replacement. All the replacement levels met the minimum strength design of $20 f_{c u}$. Figure 6 shows that the compressive strength increases as the age of the HWA-concrete increased, showing that hydration process was in progress. The behavior of the compressive strength can also be represented as: $f_{c r}=a_{2}+b_{2} x_{2}+c_{2} x_{3}$, where, $a_{2}, b_{2}$ and $c_{2}$ are constants with the values of $17.171,-2.255$ and 3.174 , respectively, $x_{2}$ and $x_{3}$ are as defined above, and are significant with $p$-values equal to 0.000 , and an interaction value of approximately $94.8 \%\left(r^{2}=94.8 \%\right)$. From Figures 7 and 8 (normality and scatter plots), it is seen that the regression model chosen is significant and perfectly describes the HWA-concrete behavior with a $P$-value of 0.000 , from the variance analysis.

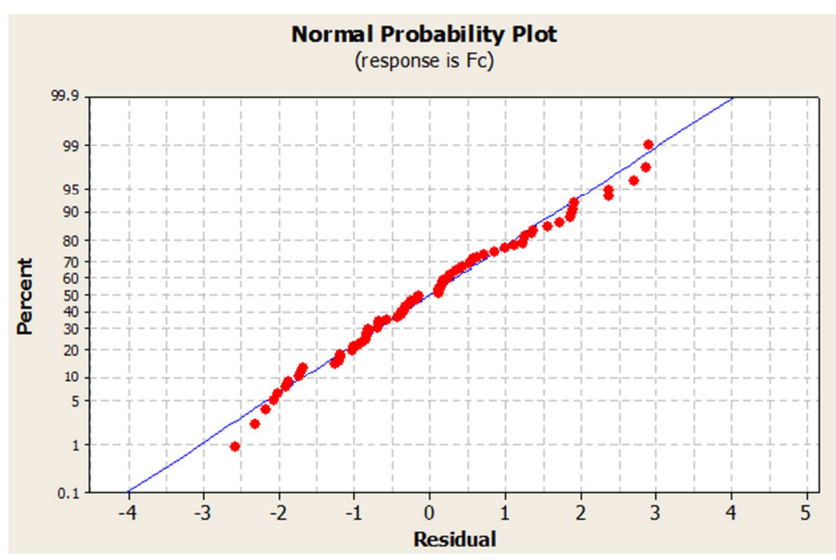

Figure 7. Normality Plot (Compressive Strength).

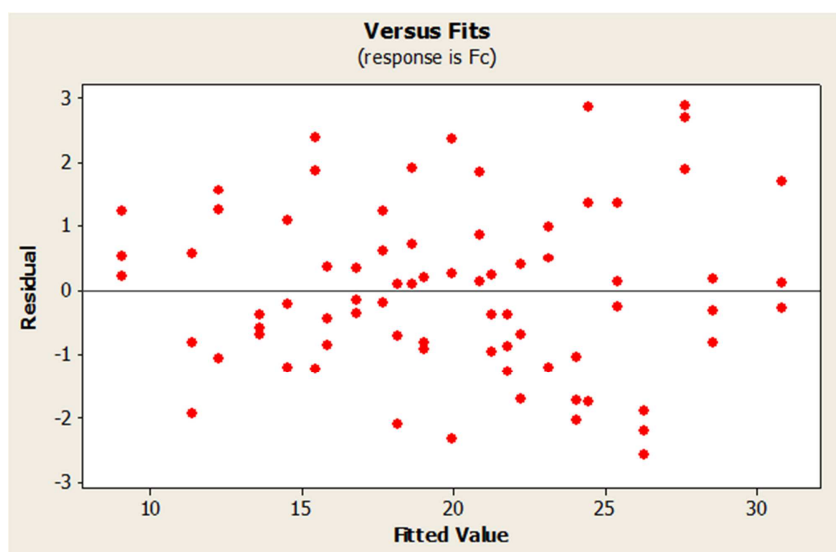

Figure 8. Residual Plot (Compressive Strength).

Relations between the compressive strength and the water absorption on one hand and the water absorption and slump on the other hand have been developed. The linear regression model for the cube compressive strength and water absorption is given as $f_{c r}=7.92+5.08 \mathrm{wa}$, with standard deviation $(s)$ of 0.9456 and correlation factor $\left(r^{2}\right)$ of $96.3 \%$. The interpretation of this relationship shows that the constants are significant with a $p$-value of $0.010<0.05$, while water absorption and regression model are significant with $P$-values of $0.003<0.05$. The relationship between the water absorption and slump on the other hand: $L n(S L)=2.52$ $+0.207 w a$, The constants are significant with $P$-values $=$ 0.000 and 0.024 while, the regression model has a $P$-value of 0.003 is significant.

\section{Conclusions}

An evaluation on the use of HWA in the production of concrete has been carried out and the following conclusions are reached on the usefulness of using such materials for concrete production.

i. The characterization of the HWA shows that it is an adequate material for concrete production. The physical and chemical properties are within the ranges 
given by the American codes of practice for waste foundry sand utilization.

ii. HWA can be classified as a retarder and thus a good material for hot weather concreting.

iii. HWA has pozzolanic properties and can reduce water absorption by approximately $25 \%$ to $54 \%$ at 90 days of curing. With this property, the durability of the concrete is enhanced and also the material HWA will perform well as a hydraulic barrier.

iv. Addition of HWA in concrete production reduces the workability of the concrete and therefore, there will be need to use this material in conjunction with a plasticizer that will enhance the workability of the concrete and encourage higher replacement levels.

v. The values of the density of HWA-concrete achieved show that it can be classified as a normal weight concrete.

vi. The compressive strength of HWA concrete decreases with increase in the replacement levels and the best behavior is at $10 \%$ replacement.

vii. The work has established linear regression relations of the compressive strength of HWA-concrete with the water absorption and slump. The regression parameters show that the models chosen to represent these behaviors are significant.

\section{References}

[1] Tsakona, M, Anagnostopoulou, E and Gidarakos, E (2007). "Hospital waste management and toxicity evaluation: A case study". Waste Management (27), 912-920.

[2] Anita, R and Kunal (2011). "Bio-medical waste incinerator ash: A review with special focus on its characteristics, utilization and leachate analysis". International Journal of Geology, Earth Sciences, vol. 1, (1), 48-58.

[3] Toyobo, AE, Baba, AO and Oyeniyi, AB (2012) "Appraisal of university teaching medical waste management in Nigeria: Case studies of university college hospital (UCH)) Ibadan and Obafemi Awolowo university teaching hospital (OAUTH), Ile-Ife". Universal Journal of Education and General Studies, vol. 1, (9), 290-297.

[4] Bassey, BE, Benka-Coker, MO and Aluyi, HAS (2006) "Characterization and management of solid medical wastes in the Federal Capital Territory, Abuja, Nigeria". African Health Science, Vol. 6, (1), 59-63.

[5] Ogbonna DN (2011) "Characteristics and waste management practices of medical wastes in healthcare institutions in Port Harcourt, Nigeria". Journal of Soil Science and Environmental Management Vol. 2, (5), 132-141.

[6] Taghipour H and Mosaferi M. (2008). "Characterization of medical waste from hospitals in Tabriz, Iran". Journal of Science of Total Environment, 1527-1535.

[7] Altin S, Altin A, Elevli B and Cerit O (2002). "Determination of hospital waste composition and disposal methods: a case study". Polish Journal of Environmental Studies, 12, (2), 251253.
[8] WHO (1985). Management of waste from hospitals and other health care establishments. Report on a WHO meeting, Bergen, 28 June -1 July 1983. Copenhagen, World Health Organization Regional Office for Europe (EURO Reports and Studies, No. 97)

[9] Lee CC, Huffman GL and Nalesnik PR (1991). "Medical waste management". Environmental Science Technology, 25, (3), 360

[10] Anita R and Kunal (2011). "Bio-medical waste incinerator ash: A review with special focus on its characterization, utilization and leachate analysis". 1 (1), 48-58.

[11] Sunday M and Agbaji EB (2012). "The influence of hospital waste dumps and incinerator ash on the receiving environment”. Advances in Applied Science Research, 3, (5), 2884-2889.

[12] Genazzini C, Zerbino, R, Ronco A, Batic O and Giacco G (2003) "Hospital waste ashes in Portland cement mortars". Cement and Concrete Research, 33, 1643-1650.

[13] Shazim AM, Muhammad AS and Muhammad BP (2011). "Utilization of hospital waste ash in concrete, Mehran University Research Journal of engineering and Technology, $22,(1), 2-8$.

[14] Siddique R (2010). "Use of municipal solid waste ash in concrete". Journal of Resources, Conservation and Recycling, $55,(2), 83-91$.

[15] Pera J., Coutaz L., Ambroise J., Chababbet M (1997). "Use of incinerator bottom ash in concrete". Cement and Concrete Research, 27, (1), 1-5.

[16] Kougemitrou I, Godelitsas A, Tsabaris C, Stathopoulos V, Papandreou A, Gamaletsos P, Economou G, Papadopoulos D (2011). "Characterisation and management of ash produced in the hospital waste incinerator of Athens, Greece". Journal of Hazardous Materials, 187, (1-3), 421-432.

[17] Anastasiadou, K, Christopoulos K Mousios E and Gidarakos E (2011). "Solidification/stabilization of fly ash and bottom ash from medical waste incineration facility, Journal of Hazardous Materials, (93), 201-208.

[18] Filipponi P, Polettini A, Pomi R and Sirini P (2003). "Physical and mechanical properties of cement-based products containing incineration bottom ash", Waste Management, (23), 145-156.

[19] BS EN 197-1:2011. Cement. Composition, specifications and conformity criteria for common cements.

[20] ASTM C191-13. Standard Test Methods for Time of Setting of Hydraulic Cement by Vicat Needle.

[21] ASTM C187-11. Standard Test Method for Normal Consistency of Hydraulic Cement.

[22] ASTM C143/C143 M-12. Standard Test Method for Slump of Hydraulic-Cement Concrete.

[23] ASTM C642 - 13. Standard Test Method for Density, Absorption, and Voids in Hardened Concrete.

[24] ASTM C192/C192M. Standard Practice for Making and Curing Concrete Test Specimens in the Laboratory. 
[25] Ontiveros JL, Kosson DS and Albert RC (1988). "Leaching characteristics and composition of residualashes from variousmunicipal incinerators. In: $\mathrm{Wu}$ (ed) International Conference on Physio-Chemical and Biological Detoxification of Hazardous Wastes, Technomic Publishing, New Jersey, $515-526$.

[26] Jaturapitakkul C and Cheerarot R (2003). "Development of bottom ash as pozzolanic material".

[27] Al-Rawas AA, Hago AW, Taha R and Al-Kharous K (2005). "Use of incinerator as a replacement for cement and sand in cement mortars". Building and Environment, (40), 12611266.

[28] ASTM D2216-10. Standard Test Methods for Laboratory Determination of Water (Moisture) Content of Soil and Rock by Mass.

[29] Stephan D, Malcki D, Knofel B, Eber R and Hardtl R (1999)."Influence of $\mathrm{Cr}, \mathrm{Ni}$, and $\mathrm{Zn}$ on the properties of pure clinker phases, Part II, C3A and C4AF". Cement and Concrete Resource, 29, (5), 651-657. 